\title{
CrimRxiv
}

\section{Innovative Data in}

Communities and Crime

\section{Research: An Example at}

the Intersection of Racial

Segregation,

Neighborhood

Permeability, and Crime

Casey Harris, Grant Drawve, Shaun Thomas, Jyotishka Datta, Hannah Steinman

Published on: Feb 28, 2022

License: Creative Commons Attribution 4.0 International License (CC-BY 4.0). 


\section{ABSTRACT}

Amidst the proliferation of community- and place-based, several innovative measurement tools have become more readily available for criminological and criminal justice researchers. The current study illustrates the utility of two novel data sources Google transportation data and municipal infrastructure files - as a means of extending studies focused on racial and ethnic segregation's effect on crime to include critical insights from environmental criminology regarding neighborhood boundary permeability. In doing so, we utilize data from over 120 block groups in Little Rock, Arkansas that include measures of Black isolation and boundary permeability: walk times to adjacent neighborhoods and thru streets captured in city infrastructure files. Our findings reveal that both segregation and neighborhood boundary permeability affect crime independently and net of key structural and spatial covariates, but that boundary permeability conditions the effect of segregation on crime. We conclude by discussing how the integration of newer and under-utilized measurement tools advances long-standing research on segregation and crime by operationalizing key theoretical concepts that have remained difficult to include using more standard secondary databases

KEYWORDS: geographic data, Google, infrastructure, segregation, crime, neighborhoods, boundaries, streets

\section{INTRODUCTION}

The fields of criminology and criminal justice continue rely heavily on secondary sources of data for measuring crime and the substantive and theoretical mechanisms thought to impact it (Nelson, Wooditch, and Gabbidon 2014; Woodward, Webb, Griffen, and Copes 2016). Secondary data are relatively easy to access in terms of both cost and time, they have been rigorously employed in theory testing, and can provide adequate detail for many research questions. The disproportionate utilization of secondary data remains particularly true of macro-level communities and crime research, which has been dominated by the use of official crime data from law enforcement agencies (e.g., the Uniform Crime Reports, National Crime Victimization Survey, etc.) that is paired with social characteristics measured in United States Census Bureau products (e.g., summary files, American Communities Survey, etc.). Such research has made invaluable contributions to the field of criminology and our 
understanding of both where crime occurs and how social, economic, and political characteristics and processes are linked to the geographic distribution of crime.

Yet, new data collection tools developed and implemented by criminal justice practitioners have been coupled with increased accessibility of data for public access and consumption (likely influenced by the Freedom of Information Act [FOIA]). Accordingly, this has spurred many contemporary law enforcement agencies and their parent cities/states to develop and maintain public-access portal to warehouse and disseminate both crime and select municipal measurements. Additionally, the proliferation of public tools that capture unique aspects of geographic spaces, including online mapping and transit products (O'Mhony 2018), has added innovative and valuable alternatives for generally observing places without being present (Vercruyssen and Loosveldt 2017). Overall, the result of such data innovation in place and crime research has been the growing leverage of scholars to examine research questions that may have previously been overlooked (Vandeviver 2014).

While research, policy, and practice have benefited from the growth in data, many of these newer sources of data remain under-utilized in place-based criminology and criminal justice. This may occur for several reasons. First, such data can be difficult to obtain and organize in a timely manner. For example, infrastructure files that include measurements of streets, sidewalks, land use, and related place-based measurements can require lengthy approval processes in order to secure access, while still requiring substantial preexisting knowledge in geographical information systems and local bureaucracy to clean and merge with other data (e.g., local crime files). Likewise, many of these new tools are iterative and updated to new versions regularly, which requires careful management and consideration for the replication of studies that employ them. Second, some of the slow uptake among community and place scholars may reflect a preference and familiarity with more traditional sources of contextual information (e.g., census data). That is, many researchers may not see the specific value of these new tools relative to the more tried-and-true data that remain staples of the crime and place literature. Third, many providers and or users of such data remain cautious so as to avoid mismeasurement in an era of "big data" (see Lynch 2018), particularly if there is the possibility of unintended social harm (Redden 2017). Finally, fourth, many of these innovative tools for crime and place research are still generating new research questions that have yet to be fully integrated into the mainstream thematic areas in criminology. Instead, these new data sources remain siloed in more niche areas for extended periods of time before becoming more integrated into more traditional research veins. As we describe below, for example, segregation and crime 
research has been rather slow to incorporate innovative methodological insights including new data tools - from the built environment literature that might clarify the ways that neighborhood connectivity works alongside and in conjunction with residential isolation.

The broadest focus of the current study is to highlight several innovative, but readilyavailable, tools for crime and place research as they can be integrated alongside more standard secondary data sources. We focus on two emerging measurements and their data sources: walk times to adjacent neighborhoods measured using Google Maps and neighborhood boundary thru streets captured by municipal infrastructure files. In demonstrating their utility, we engage several distinct literatures and examine novel research questions as to whether characteristics of neighborhood boundaries work independently and conditionally with residential segregation to impact patterns of crime. By integrating these unique data, we draw on insights from research in stratification, community and urban sociology, transportation research, and environmental criminology. Practically, as we return to in our concluding remarks, our approach offers proof-of-concept for the use of such measurement tools that might subsequently be replicated in other study sites as such data and tools become increasingly available in the future.

\section{SEGREGATION, NEIGHBORHOOD PERMEABILITY, AND CRIME: AN ILLUSTRATION}

\section{An Overview of Segregation and Crime}

Fifty years since the passage of the Fair Housing Act in 1968, few social problems generate the depth of emotion and concern as segregation within and across United States communities. Driven by historical policies rooted in overt discrimination (e.g., red lining) (Massey and Denton 1993) and even contemporary waves of immigration (Frey and Liaw 1998), the spatial patterning of different racial groups remains a central feature of many cities in the United States. For example, Lichter, Parisi, and Taquino (2015) find that, while spatial integration has become more prevalent over the past few decades, Black populations continue to lag behind other groups in the degree to which they share space with the White majority. Taken as a whole, segregation remains deeply entrenched in many large, metropolitan communities in which large populations of racial and ethnic minorities live (Krysan and Crowder 2017; see also Fowler, Lee and Matthews 2016). In turn, widespread segregation carries important 
consequences, including poorer health (Williams and Collins 2001) and lower educational attainment (Quillian 2014).

Residential segregation carries particular importance for criminology, as well. Amidst the explosion of community and place research in the past several decades (see Hipp and Williams 2020), scholars consistently find segregation impacts patterns of both offending and victimization across geographic space. For instance, a now sizeable literature shows that segregation places minority populations at greater risk of violent victimization (Xie 2010) and moderates the likelihood of arrest (Stolzenberg, D'Alessio, and Eitle 2004). Likewise, improved racial integration between 1970 and 2010 appears to account for a sizable share of the crime decline over the same period (Light and Thomas 2019). Particularly noteworthy in this literature is the isolation of Black residents, which increases crime among in the neighborhoods in which they reside (Shihadeh and Flynn 1996) and is exacerbated by socio-economic disadvantage (Peterson and Krivo 1999). Ironically, segregation's impact on crime extends beyond minority and disadvantaged communities and into white neighborhoods, as well (Krivo, Peterson, and Kuhl 2009).

To date, most of the explanations for why segregation is associated with crime center on the different social, economic, and political resources found in mostly White versus predominately Black communities. Much as Sampson and Wilson (1995) observed in their seminal piece, the most affluent minority (especially Black) neighborhoods continue to lag behind even the most disadvantaged White neighborhoods. Moreover, segregated Black communities remain physically and socially disconnected from nearby resources that might blunt the criminogenic effects of immediate disadvantages and are seen as places of neglect and disinvestment (Velez 2006). Thus, segregation produces a cycle of resource loss that compounds existing inequalities and generates crime, further reducing the number of neighborhoods capable of absorbing economic instability across a city or region (Sampson, Morenoff, and Earls 1999). Likewise, segregation undermines civic engagement and community-building (PearsonMerkowitz 2012), key mechanisms that foster social capital networks, parochial controls, and neighborhood supervisory capacity that can help prevent crime (Bursick and Grasmick 1993).

\section{Innovative Measurements from Environmental Criminology and Other Disciplines}


While research on segregation has enjoyed decades of mainstream criminological research, a somewhat separate literature within urban geography and environmental criminology emphasizes the role played by the built, physical environment in shaping crime. Highlighting infrastructure (e.g., buildings, streets, land use, and natural terrain) and spatial proximity, this line of research draws on observations from the early Chicago School sociologists (e.g., Thomas and Zaniecki, 1918; Shaw \& McKay, 1942; Park and Burgess, 1924) and contemporary geo-spatial criminologists (Brantingham and Brantingham 1995; Brantingham, Brantingham, Song, and Spicer 2020; Cohen and Felson 1979; Cornish and Clarke 1987; Eck, Clarke, and Guerette 2007; Hipp and Boessen 2013; Weisburd 2015; Wilson 1987). Such scholars show, for example, that communities with more restricted access, like gated communities, have lower levels of burglary (Addington and Rennison 2015), just as land use patterns (Browing et al. 2010; Stucky and Ottensmann 2009) and transportation networks (Sohn 2016) impact the spatial distribution of crime. Even the topography of communities affects the location of crime events (Haberman and Kelsay 2021).

At the same time, environmental criminology also emphasizes the need to capture how different geographic units are connected to each other and, in turn, how those connections affect the experiences of people in ways that shape crime (Drawve, Thomas, and Walker 2016; Thomas and Drawve 2018). We highlight that empirical research has established crime varies as a function of the ease of moving across the boundaries of neighborhoods (permeability), above and beyond proximity to high-crime surroundings. For example, studies in transportation science reveal traffic volume is positively associated with crime risk (Armitage 2007), while greater connectivity within street networks increases rates of crime, as well (Johnson and Bowers 2010). In their own analysis, Groff and colleagues (2014) find that municipalities with more permeable boundaries tend to have more unexpected increases in violent crime, which they attribute to growth in shared activity spaces that intensify the risk of violence. Similarly, Sohn (2016) shows that neighborhoods with greater walkability and more intersections at their boundaries have higher rates of residential burglary and robbery, net of other key features of those neighborhoods (see also Cozens and Love 2009; for an exception, see Sohn, Yoon, and Lee 2018). While results across other studies of permeability remain somewhat mixed depending on the type of crime examined (see review by Groff et al. 2014), the manner and degree to which neighborhoods are more/less accessible to their surroundings remains impactful for the incidence of crime. 
Equally important to this substantive insight, the same built environment literature has contributed to the innovative use of data that capture and operationalize key physical and social attributes of neighborhoods that are theoretically important (we return to theory below). For instance, in examining the distribution of robbery and burglary, Sohn (2016) draws measures of boundary permeability from the Washington State Geospatial Data Archive (WAGDA), a unique example of a localized geographic warehouse maintained by the University of Washington. In a similar manner, Johnson and Bowers (2010) draw on ordnance survey data maintained by the municipality of Merseyside in the United Kingdom in order to construct street network measures. Finally, more recent scholarship by Connealy (2021) leverages Google Street View to conduct systematic social observations of robbery hot spots. Thus, as Vandeviver (2014: 5) summarizes in his review of criminological data applications, these innovative measurement tools "help researchers reduce costs and overcome particular difficulties in their research" that may continue to plague studies that rely on more traditional primary and secondary data sources.

\section{Innovative Data to Connect Segregation-Crime and Neighborhood Permeability Research}

The current study seeks to connect these two literatures while demonstrating the utility of innovative measurement tools by exploring how segregation and the ease of movement into and out of neighborhoods (boundary permeability) each relate to crime, as well as how boundary permeability might differ in its association with crime depending on the degree of Black residential isolation. In doing so, we fill a critical gap in prior research. First, to our knowledge, no prior research examines how both segregation and boundary permeability impact crime across geographic units. A sizeable literature describes the consequences of segregation on crime, just as environmental criminology provides evidence that boundaries and their rigidity or porousness affect the spatial location of crime (e.g., Groff et al. 2014; Kim and Hipp 2018; Sohn 2016). Yet, we are aware of no study that conjoins both.

We note that our examination of segregation, permeability, and crime not only bridges disparate literatures, but also engages theoretical frameworks in macro-level criminology more broadly through the implementation of new data sources. That is, these newer, innovative tools for capturing built environment features allow us to operationalize important mechanisms - particularly boundary permeability as distinct from segregation - that parallel key themes from several prominent theories. Thus, 
ours is not an atheoretical approach designed to utilize data for their own sake, but rather to showcase those data as they are theoretically relevant. For example, the systemic model of social disorganization emphasizes the ability of residents to establish and maintain social ties that help to regulate social control (Bursik and Grasmick 1993). As such, the isolation (segregation) of specific groups combined with a lack of connectivity across neighborhoods could restrict social network diversity and, especially, bridging capital (Putnam 2001). In this manner, both segregation and neighborhood permeability work independently and in conjunction to knife off the formation of critical social resources, entrench disorganization and disadvantage, and reduce the social control capacity of communities necessary for crime control. Such expectations are also broadly in line with the civic community thesis, which emphasizes the importance of community social capital as a means of developing social control (Blanchard and Matthews 2006; Lee 2008; Lee and Thomas 2010; Tolbert, Lyson and Irwin 1998).

Alternatively, anomie perspectives see the conveyance of belonging and community as essential to purveying pro-social norms, including conformity to the law and avoidance of crime (Merton 1957). Rather than focusing on the physical and social conditions of neighborhoods as they undermine social control, such conditions might foster anomie or normative deregulation among populations who reside outside of the mainstream (i.e., the dominant, White majority). Thus, the degree to which residents of a neighborhood are socially isolated from those norms and/or feel a further sense of isolation by having few means of connecting to those norms in surrounding areas, the more likely feelings of normlessness and anomie are to develop within those neighborhoods. The result is a high rate of crime in the most isolated locales coupled with lower levels of boundary permeability.

Finally, routine activities theory suggests that both segregation and boundary permeability matter for neighborhood levels of crime by shaping activity spaces. From this perspective, crime occurs when motivated offenders coincide in time and space with likely targets in the absence of capable guardians (Cohen and Felson 1979). In this manner, segregation can increase crime to the extent that it concentrates motivated offenders into places with fewer the capable or willing guardians to intervene. Shaping these routine activities are the nodes, paths, and edges present in individuals' routines (see Brantingham \& Brantingham 1993, 1995). Where nodes operate as activity spaces where people spend a significant amount of time connected by paths, edges are both social and physical boundaries that dictate and direct the mobility of people in ways that shape their views of criminal opportunity. Important to 
our current study, Brantingham and Brantingham (1993) even argue that the physical connections between places through road networks can affect how far crime travels. The ease of access throughout a given place, community, or city influences the awareness space and general knowledge of specific areas, leading to variation in crime occurrence.

On the other hand, the theoretical expectations of some urban planning scholars contrasts with these criminological approaches and would see permeability as potentially problematic for both segregation and crime. Indeed, Jacobs' (1961) seminal writings in The Death and Life of Great American Cities contrasts in some ways with the approach of prominent place-based theorists of crime as she argues that the complexity of human connection - and the social control against things like crime that such connection brings - can be destroyed by large-scale urban renewal projects, including highways and roads. Thus, where place-based criminologists see permeability as reducing deleterious conditions through connectivity, some urban renewal scholars might argue that greater permeability simultaneously creates more and harder boundaries to further entrench segregation, upset social life, and could generate crime.

\section{STUDY SITE AND PARAMETERS OF THE CURRENT ANALYSIS}

As we move to extend insights from these theoretical perspectives, our own study focuses on Little Rock, Arkansas, a city known for both segregation and crime. For example, a recent article in The Atlantic describes the persistent racial divide in Little Rock, Arkansas, including the historic 1957 integration of Central High School, the subsequent growth of the mostly White suburbs in the 1960s and 1970s, and the recent controversy surrounding public and charter schools in minority neighborhoods (Semuels 2016). Pervasive throughout are the distinctly racialized neighborhoods that pattern city life. The author notes:

"In the decades since the schools were first integrated, Little Rock has become a more residentially segregated city, with white residents in the northwest part of town and blacks in the southwest and south." (Semuels 2016: 1).

Little Rock is the capital city of Arkansas with 213,000 residents and is the largest city in Arkansas. The population within Little Rock is about 50 percent White and 42 percent Black (Census 2019). Critical for the execution of the current study, the authors have an on-going data sharing memorandum of understanding with the city of Little Rock specifically that includes a data sharing provision. Little Rock is about 121 
square miles and ranks among the top ten cities with more than 100,000 residents in terms of both violent and property crime rates. High crime rates coupled with the high degree of diversity and segregation (see below) makes Little Rock a unique landscape in which to examine our research questions. Furthermore, in 2016, the city of Little Rock joined What Works Cities (https://whatworkscities.bloomberg.org), and in 2021 achieved Silver Certification for their local efforts in data collection and transparency. Little Rock's general movement towards data accessibility for the public not only assists us as researchers but serves as an example of the innovative tools and sources that have become increasingly common in municipalities across the United States over the past decade.

Within Little Rock, we draw data from four sources, some available through the onlinedata-portal that reflects the kind of emerging data tool that continues to be underutilized within criminological research broadly and crime and place research specifically. First, crime data are taken from the Little Rock Police Department's (LRPD) offenses known. Second, we leverage city infrastructure data files for the measurement of neighborhood boundary thru-streets. Likewise, third, we estimate travel (walk, drive, transit) times as provided by Google Maps to construct an alternative or additional measure of neighborhood boundary permeability. Finally, fourth, we calculate measures of segregation and other macro-social characteristics using 2015 American Community Survey (ACS) 5-year estimates.

Our unit of analysis is the census block group, the "smallest geographic entity for which the decennial census tabulates and publishes sample data" and that generally contain between 600 and 3000 individuals (United States Census Bureau 2019). Census block groups are a convenient proxy for neighborhoods in Little Rock in that they reflect colloquially distinct areas that, while part of the same census tract, are often referred to distinctly by city agencies and residents in light of their physical features and transportation networks. We restrict our sample of block groups to those with more than 600 individuals and at least 100 Blacks. The latter criteria are used in order to ensure the stability of our segregation measure described below. Our final sample includes 120 block groups out of a total of 155, representing nearly 80 percent of all block groups in the city of Little Rock.

\section{DEPENDENT VARIABLES}

Crime data are obtained from Little Rock Police Department for 2014 - 2016.1 We limited our analysis to four crime types: homicide, aggravated assault, burglary, and larceny. On the one hand, homicide and burglary are among the most serious violent 
and property crimes, respectively, making them among the more reliably reported offenses. On the other hand, aggravated assault and larceny represent more common violent and property offending, allowing us to explore how segregation and neighborhood permeability are associated with especially prevalent crimes, while mitigating small-count issues associated with more serious (but rare) criminal events. Notably, as described in our sensitivity analysis, the use of robbery and motor vehicle theft as alternative offenses produced substantively similar findings, as did models for the violent and property indexes (see below). Crime data for 2014 had to be geocoded while 2015 and 2016 data obtained latitude/longitude-specific descriptions for each criminal event. Each specific crime type was aggregated to a count per respective block group, providing neighborhood counts.

\section{MEASUREMENT OF SEGREGATION}

Our key independent variable is the Black isolation index ( $\left.\mathrm{P}^{*}\right)$. One of the most common measures of segregation (Shihadeh and Flynn 1996), isolation ranges from 0 to 1 and reflects the average proportion of Black residents in a randomly selected Black resident's block (Massey and Denton 1988) and is calculated as follows:

\section{[Equation]}

Where $x i$ is the total number of Black residents of a block, $X$ is the total number of Black residents in the block group, and $t i$ is the total population of block $i$. Importantly, this measure takes into account both the distribution of groups and their proportions within the city and captures "the extent to which minority members are exposed only to one another" and, hence, spatially isolated from non-Black residents (Massey and Denton 1988: 288). Formally, this measure is interpreted as the probability that a randomly drawn Black resident shares a block group with another Black resident and has been widely used in criminological research (Feldmeyer, Harris, and Scroggins 2015; Shihadeh and Flynn 1996). Alternative specifications of segregation using the Black-White index of dissimilarity produce substantively similar results.

As described below in Table 1, the average Little Rock block group contains a high degree of Black isolation relative to other cities throughout the United States (Wilkes and Iceland 2004). In turn, we also note that prior research finds extreme segregation (i.e., the highest levels of isolation) to be the most deleterious for community wellbeing (Krivo and Peterson 1996; Massey and Denton 1993; Shihadeh 2009; Shihadeh and Flynn 1996; Wilson 1987). To that end, we create dummy variables for those block 
groups that were in the highest and lowest quartiles of $\mathrm{P}^{*}$ - high Black isolation and low Black isolation, respectively.

\section{NEIGHBORHOOD PERMEABILITY}

To measure neighborhood permeability, we construct two separate measures. First, we use administrative infrastructure street files for the City of Little Rock to identify the number of thru streets that travel into and out of each adjoining block group. Streets that form the line of demarcation of block groups are not counted toward connecting streets, nor are those streets that begin or end at that boundary but do not carry over into another block group. We calculated the average number of thru streets across all adjoining block groups, taking into account the number of neighboring block groups.2 A higher number indicates a greater degree of permeability between a block group and its neighbors.

Second, using Google's public mapping feature, we calculated the walking time from the center of one block group to all of its adjoining/continuous neighbors (i.e. centroid to centroid). Walk times were all calculated on the same day and time (a weekday during business hours) to ensure comparability across all block groups. We subsequently divided each walking time by the Euclidean distance to each neighboring block group, and then calculated the average walk time to all adjoining neighbors. A lower number indicates a greater degree of permeability between a block group and its neighbors.

\section{CONTROL VARIABLES}

In order to account for other key correlates of crime, as well as socio-structural conditions linked to neighborhood permeability and Black isolation, we control for disadvantage using a principal component analysis (PCA) combining (a) the percent of residents of each block group that are below the poverty line, (b) the percent who lack a high school degree, (c) the percentage of families headed by a female only and with children under 18 years of age, and (d) the percentage of residents who are enrolled in the Supplemental Nutrition Assistance Program (SNAP). Given our unit of analysis and its importance in prior research on permeability, we created spatial lags (Queen's 1st order) of all of our crime measures in order to parse out the effect of proximity to high/low crime block groups.3 Additionally, we include a multi-group entropy score for 
each block group to measure racial/ethnic diversity (Reardon and Firebaugh 2002), as well as the logged population density. All multivariate models described below also include an exposure term for the total population.

\section{ANALYTIC TECHNIQUES}

Our analysis unfolds in three steps. First, we present descriptive statistics for our sample of block groups. Because of our focus on extreme segregation, we present these descriptive statistics for all Little Rock block groups, as well as for the those with the lowest and highest levels of Black isolation. Second, we estimate a series of negative binomial regression models predicting our crime event outcomes, controlling for both segregation and neighborhood permeability. Given the nature of our crime counts and their over-dispersion as revealed by diagnostic statistics, negative binomial models using the Poisson distribution are preferable to standard ordinary least squares regression (Osgood 2000). These models bear directly on our first aim in exploring how both segregation and neighborhood boundary permeability are both related to violent and property crime. Third, we estimate identical negative binomial regression models, but separately for low versus high Black isolation block groups. This latter method of model disaggregation is advantageous because (a) it allows us to examine how all of our independent variables, including neighborhood permeability, do or do not differ in their association with crime in neighborhoods characterized by high versus low levels of segregation without having to estimate a large number of interaction terms, as well as (b) getting directly at our second research question regarding whether neighborhood permeability impacts crime differently in places with higher or lower degrees of segregation. ArcGIS Pro, GeoDa, and STATA were used for all analyses.

\section{RESULTS}

\section{DESCRIPTIVE STATISTICS}

We begin our presentation of the results by examining the means and standard deviations of our key variables as displayed in Table 1. The first two columns provide descriptive statistics for all of the block groups meeting our selection criteria in Little Rock ( $\mathrm{n}=124$ ). Columns 3-4 and 5-6 show the same descriptive statistics for those block groups falling into the lowest quartile and highest quartile if Black isolation, 
respectively. Finally, for ease of interpretation, column 7 calculates the percentage difference in means between the lowest and highest quartiles of Black isolated neighborhoods.

\section{(TABLE 1 ABOUT HERE)}

We note four findings. First, the typical block group in Little Rock experiences .30 homicides, 7.70 aggravated assaults, 10.94 burglaries, and 50.62 larcenies per 1,000 residents. Second, the typical neighborhood contains an average of 1.71 thru streets per neighboring block group with an average walking time of 34.88 minutes. Third, as noted briefly above, there is a relatively high degree of Black isolation in the typical Little Rock neighborhood. Across all block groups, the average probability that a randomly drawn Black resident shares a block group with another Black resident is .67. However, there is considerable variation in racial isolation across the city as evidenced by index scores of .27 in the lowest quartile of block groups and .95 in the highest quartile of block groups. This represents, on average, more than a 250 percent difference between block groups with low and high levels of Black isolation. For comparison, the average metropolitan area in 2010 had a mean Black isolation score of .46 (Iceland and Sharp 2013).

Finally, fourth, there are important differences in terms of crime, permeability, and our control variables between those neighborhoods with high versus low levels of Black isolation. For example, except for the larceny rate, the crime rate in the most segregated block groups is between 126 and 1,500 percent higher than in the least segregated block groups. Likewise, average permeability is greater in the most segregated block groups than in the least segregated ones: the average number of thru streets is over 150 percent greater, while the average walk time is roughly 41 percent lower. Finally, those block groups characterized by the highest levels of Black isolation have considerably greater levels of poverty, lower levels of educational attainment, more female headed households with children, and a greater degree of government SNAP assistance. Thus, block groups with greater Black isolation are more disadvantaged, permeable to their neighboring block groups, and crime prone.

\section{MULTIVARIATE MODELS: INDEPENDENT ASSOCIATIONS}

Next, we turn to addressing our first research question regarding the impact of permeability and segregation on crime, net of key macro-social controls. To that end, 
Table 2 displays key coefficients from our negative binomial models predicting homicide, aggravated assault, burglary, and larceny. Though not shown, all models include controls for racial/ethnic diversity, logged population density, an exposure term for the total population, and clustered standard errors to account for shared variance among block groups within the same census tract. Importantly, models removing population density and the diversity variables produce nearly identical results.

\section{(TABLE 2 ABOUT HERE)}

First, we find that, with the exception of homicide, neighborhood permeability is statistically significantly and positively related to crime, net of other macro-social characteristics. For aggravated assault, burglary, and larceny, block groups with more average thru streets tend to have more incidents of each offense $(p<.01)$, while block groups with lower walk times tend to have more incidents $(\mathrm{p}<.001)$. Second, segregation in the form of Black isolation is positively associated with crime net of other key variables, with the exception of larceny. Thus, in response to our first research question, both neighborhood permeability and segregation have unique, independent relationships with crime, net of other key controls. As a third finding, we also note that several other measures have important associations with our violent and property crimes. For instance, proximity to other high-crime neighbors is associated with greater incidence of aggravated assault, while more disadvantaged block groups tend to have more incidents of aggravated assault and, to a lesser extent, homicide and larceny.

\section{MULTIVARIATE MODELS: CONDITIONAL ASSOCIATIONS}

Our next step is to untangle the conditional effect of neighborhood permeability and segregation as they impact our measures of crime. To address this, Table 3 displays the coefficients from negative binomial models regressing crime counts on average thrustreets and key controls (Panel A) and average walk time and key controls (Panel B). For each panel, we run models separately for those block groups in the lowest quartile for the Black isolation index as shown in odd numbered columns, as well as for those block groups in the highest quartile for the Black isolation index shown in even numbered columns. We would conclude that permeability differs in its association with crime in the least versus most segregated neighborhoods if the permeability coefficients for the same offense vary systematically. 
(TABLE 3 ABOUT HERE)

The most important finding from Table 3 is that neighborhood permeability - whether measured as the average number of thru-streets or average walk time - is associated with crime in the most segregated block groups but not in the least segregated block groups, controlling for other key macro-social traits.4 For instance, panel A shows that a greater number of thru-streets at block group boundaries are associated with greater incidence of aggravated assault $(b=.23, \mathrm{p}<.001)$, burglary $(b=.12, p<.05)$ and larceny $(b=.12, p<.05)$ in those Little Rock block groups with the highest levels of Black isolation, whereas there is no relationship at all in those characterized by low levels of Black isolation (in fact, several of the coefficients are in the opposite direction). Likewise in Panel B, among the most segregated Little Rock block groups, greater walk times are associated with lower incidence of homicide, assault, burglary, and larceny - or, put another way, greater permeability is associated with more of each type of crime, net of other key controls.

Among our other variables, disadvantage is associated with more assault only in block groups with the lowest levels of Black isolation. In contrast, with the exception of homicide, the spatial proximity to crime is associated with more immediate crime in both low and high segregation block groups for assault and (to a lesser extent) both types of property crime. All other controls were non-significant.

\section{SENSITIVITY CHECKS}

In addition to the models displayed in Tables 2 and 3, we also estimated a number of alternative models to explore the robustness of our results. In particular, we (a) construct models that removed racial/ethnic diversity and population density, (b) include alternative measures of permeability using driving and transit times, (c) include a measure of residential mobility defined as the percentage of block group residents living in a different house than the year prior, $(d)$ predict robbery and motor vehicle theft, (e) predict total index violence and property crime offending, and (f) substituted spatially lagged measures of disadvantage, percent Black, and racial/ethnic diversity for the lagged crime variables. Results from each of these additional analyses parallel our substantive findings and suggest that our results are not overly sensitive to modeling choices. 


\section{DISCUSSION}

Broadly, our goal has been to illustrate the value of two innovative data sources particularly (1) Google Map travel times to surrounding neighborhoods and (2) infrastructure data measures of thru-streets as they connect across neighborhood boundaries - for communities and crime scholarship by examining research questions derived from largely disconnected lines of inquiry. Although there is a fairly wellestablished literature on the criminogenic influence of residential racial segregation, another empirical literature focusing on the link between neighborhood boundary permeability and crime developed somewhat separately. The latter has increasingly emphasized innovative data tools for operationalizing characteristics of geographic units and their connections. Thus, we argued that adjoining these two disparate literatures had the potential to provide a more comprehensive understanding of the spatial patterning of crime between neighborhoods, but also serves as a case study of how new measurement tools might offer methodological leverage to move beyond traditional secondary data sources in important theoretical ways.

Results from the empirical analysis of block groups in Little Rock, AR provided a fairly unambiguous picture with three main conclusions. First, the most segregated neighborhoods, on average, have porous boundaries or greater connectivity to adjoining neighborhoods. In fact, compared to neighborhoods with low levels of segregation, extremely segregated neighborhoods have 150 percent more thru streets and a 40 percent lower average walking times to adjoining neighborhoods. This is simultaneously a basic and profound finding considering residential racial segregation has been a primary mechanism by which minority groups, particularly African Americans, have been isolated from mainstream American society. Segregated minority communities are often overlooked places of neglect and disinvestment in which residents are precluded from sharing space with more advantaged others and it might be expected that the boundaries of such communities would be purposefully made more rigid. In contrast, our findings suggest that neighborhood boundaries are actually more permeable in those neighborhoods in which Black individuals are primarily exposed to only other Black individuals. A visual inspection of our data reveals why: the most isolated Black neighborhoods are permeable with each other, but not with more racially integrated neighborhoods. While it is beyond the scope of the current study to untangle the manner in which permeability affects crime uniquely 
across different boundary types (e.g., segregated-to-segregated versus segregated-tointegrated), we return to this issue briefly in discussing directions for future research.

As a second finding, our analyses indicated that both residential segregation and the rigidity/porousness of neighborhoods have unique and significant relationships with both violent and property crime. As such, despite some conceptual and empirical overlap between segregation and boundary permeability, measures of each construct had empirically distinct effects on crime. Neighborhoods with more permeable boundaries had, on average, more aggravated assault, burglary, and larceny. Moreover, the results suggested that measures of neighborhood connectivity that tap different modes of transportation (walking and motor vehicle) were each significantly associated with the spatial patterning of violent and property crime. As for segregation, in line with the extant literature, levels of homicide, aggravated assault, and burglary were greater in neighborhoods in which Black residents were more isolated from Whites.

Third, the criminogenic influence of boundary permeability appeared to be limited to only the most extremely segregated neighborhoods. That is, the average number of thru streets and the average walk time to adjoining neighborhoods were strongly associated with levels of violent and property crime only in those neighborhoods in which racial isolation was most pervasive. Thus, it appeared that such neighborhoods suffered from the double disadvantage of being at once isolated from mainstream society and simultaneously more physically connected to adjoining neighborhoods that, in turn, provided a conduit for more crime (perhaps by facilitating victimization or the attraction of offenders to suitable targets outside of guardianship).

By emphasizing the important intertwining of residential racial segregation and neighborhood permeability, our findings speak more broadly to two issues. First, there remains fruitful ground for integrating new and innovative data tools - including Google Maps/Earth and local infrastructure files - into more "traditional" areas of research in criminology. Scholars of segregation and crime have made profound contributions to knowledge relying disproportionately upon secondary macro-level databases that are readily accessible and commonly employed in a host of social science fields. Nevertheless, as cities and states expand their data collection and dissemination strategies (like Little Rock), the opportunity for exploring new and exciting research questions has grown. Our findings illustrate one such opportunity.

Second, our findings are important for theories of communities and crime that can be operationalized using innovative data sources. On the one hand, systemic models of disorganization emphasize that greater connectivity to adjoining neighborhoods might 
attenuate levels of crime by facilitating the formation of social bonds, networks, and resources. We find little support for this and, instead, our results show that in the most segregated neighborhoods porous boundaries may in fact further undermine the already weakened social control capacity of the community in ways that exacerbate crime. On the other hand, per anomie/strain perspectives, greater access to adjoining neighborhoods may be associated with higher levels of crime depending on which neighborhoods those connections are made to. For example, our finding that permeability exacerbates crime in the most isolated neighborhoods (and that the most segregated block groups are connected to others with high Black isolation) might reflect a shared sense of normlessness among the most segregated places, as well as the comparative sense of isolation relative to nearby integrated neighborhoods. Finally, our findings underscore the conditional nature of extreme segregation and neighborhood permeability in support of routine activities approaches. That is, neighborhood connectivity may exacerbate levels of crime by facilitating the movement of people across the built environment, especially in the most segregated locales. Thus, porous boundaries and segregation result in the convergence of offenders in time and space with potential targets in neighborhoods with a weakened social control capacity (Cohen and Felson 1979).

\section{DATA INNOVATION MEETS SUBSTANCE: LIMITATIONS AND FUTURE RESEARCH}

Overall, the results of the current study offer interesting directions for future research. On the one hand, there remains the need to explore the theoretically relevant intervening mechanisms that link neighborhood permeability, segregation, and crime, including normative disconnect, activity spaces and crime displacement, or social capital networks. Our study was limited to neighborhoods in a single city that may not be generalizable to other places. Indeed, Little Rock has a unique history of segregation, most notably Governor Orval Faubus's refusal to comply with the Supreme Court ruling in Brown v. Board of Education and his use of the Arkansas National Guard to prevent the integration of Central High School. As such, future research should explore the robustness of our results by seeking out the same kinds of innovative data sources as they might apply in a multitude of cities.

On the other hand, a fitting next step would be to integrate Google related services to conduct systematic social observation in Little Rock and other study site communities. Given the important legacy of such methodology, including the Project on Human Development in Chicago Neighborhoods (PHDCN - Sampson and Raudenbush 1999, 
2004; Raudenbush and Sampson 1999), popular web tools like Google Earth, Street View, and My Maps provide researchers and practitioners the ability to view, code, and add context to the environments being studied (Vandeviver 2014). As an example, Odgers and colleagues (2013) outline a systematic social observation approach using Google Street View to assess neighborhood conditions (Odgers, Caspi, Bates, Sampson, and Moffitt 2013). This has been further adapted to other criminological research applications (e.g., Connealy 2021; Hsu and Miller, 2017; Langton and Steenbeek 2017; Sytsma, Connealy, and Piza 2021; Vandeviver 2014). Such research would be critical for not only advancing the literature on segregation, permeability, and crime by contextualizing the perceived disorder of segregated and permeable communities, but also would provide an alternative to the field observation of each geographic environment.

Finally, more research is needed that untangles the impact of boundary permeability on crime across different types of boundaries. In our own data, we noted that the most segregated neighborhoods had the shortest walk times and most thru streets, but that connectivity was primarily to other neighborhoods with high levels of Black isolation. Does permeability matter for crime at the boundary of similarly segregated neighborhoods in the same way as at the boundaries of segregated and integrated neighborhoods? This remains perhaps the most central question to emerge from our study, and one that can more fully establish how physical features of neighborhood boundaries work independently and in tandem with racial segregation to shape patterns of crime. Central to the theme of data innovation, such a project would entail the same kinds of infrastructure and transportation data we employ here and (possibly) related databases that have yet to be leveraged.

\section{WHY INNOVATION IN MEASUREMENT REMAINS IMPORTANT}

Our illustrative case study of segregation, permeability, and crime in Little Rock was chosen strategically for both substantive and methodological reasons. As a substantive issue, patterns of residential settlement among different populations living within the United States and their impact on social and behavioral outcomes have long garnered attention. At the same time, advances within criminology, sociology, geography, and urban studies have further highlighted the importance of understanding the ways physical space shape how individuals interact with their environment and each other. Methodologically, Little Rock has been among the most data-forward cities in the 
heartland region, providing the kinds of detailed physical, social, and environmental data that criminologists and other social scientists find increasingly valuable.

Like in Little Rock, the growing availability of and access to new sources of data across municipalities promises both the ability to explore theoretically informed research questions and to promote data-driven, evidence-based decision making. Indeed, Little Rock's data team has explicitly noted the role that data collection and dissemination will have on local policies and practices (see https://data.littlerock.gov). Beyond local data repositories, even national-level agencies and organizations have begun to generate similarly valuable innovative data tools. For example, the Department of Homeland Security maintains the Homeland Infrastructure Foundation-Level Data open data portal (see https://gii.dhs.gov/hifld/) that includes locational data on public venues, public health, law enforcement agencies, ambient population, food industry, education, emergency services, commercial, and agriculture. Additionally, the US Federal Government recently developed and improved GeoPlatform to increase crossagency collaborative of geographic data in a Findable, Accessible, Interoperable, and Reusable (FAIR) manner (see https://www.geoplatform.gov/). Thus, researchers and practitioners will increasingly have the opportunity to explore such data sources more regularly to better understand critical and emerging criminological and criminal justice questions. As the current study shows, even research areas that have seen decades of dedicated scholarship devoted to them remain fertile ground for new and exciting possibilities as new data proliferate and push both theoretical and methodological boundaries. 
Page Break

\section{REFERENCES}

Armitage, Rachel. 2007. "Sustainability vs. Safety: Confusion, Conflict and Contradiction in Designing out Crime." in Imagination for Crime Prevention: Essays in Honour of Ken Pease. Vol. 21, Crime Prevention Studies, edited by K. J. Bowers, G. Farrell, S. D. Johnson, and M. Townsley. New York: Cullompton: Lynne Rienner Publishers.

Blanchard, Troy and Todd Matthews. 2006. “The Configuration of Local Economic Power and Civic Participation in the Global Economy." Social Forces 84(4): 2241-2258.

Brantingham, Patricia and Paul Brantingham. 1995. “Criminality of Place: Crime Generators and Crime Attractors." European Journal of Criminal Policy and Research, 3: 5-26.

Brantingham, P.J., Brantingham, P.L., Song, J., \& Spicer, V. 2020. Crime hot spots, crime corridors, and the journey to crime: An expanded theoretical model of the generation of crime concentrations. In K.M. Lersch and J. Chakraborty (eds.) Geographies of Behavioral Health, Crime, and Disorder. GeoJournal Library, 126:61-86. Springer.

Bursik, Robert J., and Harold G. Grasmick. 2002. Neighborhoods and Crime: The Dimensions of Effective Community Control. Boston, MA: Lexington Books.

Cohen, Lawrence E., and Marcus Felson. 1979. "Social change and crime rate trends: A routine activity approach." American Sociological Review, 444(4): 588-608.

Connealy, N.T. 2021. “Understanding the predictors of street robbery hot spots: A matched pairs analysis and systematic social observation." Crime \& Delinquency, 67(9): 1319-1352.

Cornish, Derek B., and Ronald V. Clarke. 1987. "Understanding Crime Displacement: An Application of Rational Choice Theory." Criminology 25(4): 933-948.

Cozens, Paul, and Terence Love. 2009. "Manipulating Permeability as a Process for Controlling Crime: Balancing Security and Sustainability in Local Contexts." Built Environment 35(3): 346-365.

Drawve, Grant, Shaun A. Thomas, and Jeffery T. Walker. 2016. “Bringing the Physical Environment Back into Neighborhood Research: The Utility of RTM for Developing an 
Aggregate Neighborhood Risk of Crime Measure." Journal of Criminal Justice 44: 2129.

Eck, John E., Ronald V. Clarke, and Rob T. Guerette. 2007. “Risky Facilities: Crime Concentration in Homogeneous Sets of Establishments and Facilities." Crime Prevention Studies 21: 225-264.

Feldmeyer, Ben, Casey T. Harris, and Jennifer Scroggins. 2015. “Enclaves of Opportunity or 'Ghettos of Last Resort?' Assessing the Effects of Immigrant Segregation on Violent Crime Rates." Social Science Research 52:1-17.

Fowler, Christopher S., Barrett A. Lee, and Stephen A. Matthews. 2016. "The Contributions of Places to Metropolitan Ethnoracial Diversity and Segregation: Decomposing Change Across Space and Time." Demography 53(6): 1955-1977.

Frey, William H., and Kao-Lee Liaw. 1998. "Immigrant Concentration and Domestic Migrant Dispersal: Is Movement to Nonmetropolitan Areas ‘White Flight'?” The Professional Geographer 50(2): 215-232.

Groff, Elizabeth R., Ralph B. Taylor, David B. Elesh, Jennifer McGovern, and Lallen Johnson. 2014. "Permeability Across A Metropolitan Area: Conceptualizing and Operationalizing a Macro Level Crime Pattern Theory." Environment and Planning 46(2): 129-152.

Haberman, Cory P. and James D. Kelsay. 2021. "The Topography of Robbery: Does Slope Matter?”. Journal of Quantitative Criminology 37: 625-645.

Hipp, John R. and Adam Boessen. 2013. "Egohoods as Waves Washing across the City: A New Measure of “Neighborhoods"." Criminology 51(2): 287-327.

Hipp, John R. and Seth A. Williams. 2020. "Advances in Spatial Criminology: The Spatial Scale of Crime." Annual Review of Criminology 3: 75-95.

Hsu, K. H., \& Miller, J. (2017). Assessing the situational predictors of drug markets across street segments and intersections. Journal of Research in Crime \& Delinquency, 54(4), 902-929.

Iceland, John, and Gregory Sharp. 2013. “White Residential Segregation in U.S. Metropolitan Areas: Conceptual Issues, Patterns, and Trends from the U.S. Census, 1980 to 2010." Population Research and Policy Review 32(5):663-86. 
Jacobs, Jane. 1961. The Death and Life of Great American Cities. New York: Random House.

Johnson, Shane D., and Kate J. Bowers. 2010. "Permeability and Burglary Risk: Are Culde-Sacs Safer?” Journal of Quantitative Criminology 26(1): 89-111.

Kim, Young-An, and John R. Hipp. 2018. "Physical Boundaries and City Boundaries: Consequences for Crime Patterns on Street Segments?" Crime \& Delinquency 64(2):227-54.

Krivo, Lauren J., and Ruth D. Peterson. 1996. “Extremely Disadvantaged Neighborhoods and Urban Crime." Social Forces 75(2): 619.

Krivo, Lauren J., Ruth D. Peterson, and Danielle C. Kuhl. 2009. “Segregation, Racial Structure, and Neighborhood Violent Crime." American Journal of Sociology 114(6): 1765-1802.

Krysan, Maria, and Kyle Crowder. 2017. Cycle of Segregation: Social Processes and Residential Stratification. New York: Russell Sage Foundation.

Langton, S. and Steenbeek, W. 2017. "Residential burglary target selection: An analysis at the property-level using Google Street View.” Applied Geography 86: 292299.

Lee, Matthew R., and Shaun A. Thomas. 2010. "Civic Community, Population Change, and Violent Crime in Rural Communities." Journal of Research in Crime and Delinquency 47(1): 118-47.

Lee, Matthew R. 2008. "Civic Community in the Hinterland: Toward a Theory of Rural Social Structure and Violence.” Criminology 46:447-78.

Lichter, Daniel T., Domenico Parisi, and Michael C. Taquino. 2015. “Toward a New Macro-Segregation? Decomposing Segregation within and between Metropolitan Cities and Suburbs." American Sociological Review 80(4): 843-873.

Light, Michael T., and Julia T. Thomas. 2019. "Segregation and Violence Reconsidered: Do Whites Benefit from Residential Segregation?” American Sociological Review 84(4): 690-725.

Lynch, J. 2018. "The 2017 Presidential Address to the American Society of Criminology: Not even our own facts: Criminology in the era of big data." Criminology, 
56(3): 437-454.

Massey, Douglas S., and Nancy A. Denton. 1988. "The Dimensions of Residential Segregation." Social Forces 67(2): 281.

Massey, Douglas S., and Nancy A. Denton. 1993. American Apartheid: Segregation and the Making of the Underclass. Cambridge, Mass.: Harvard Univ. Press.

Merton, Robert K. 1957. Social Theory and Social Structure, New York, NY: Free Press.

Nelson, M.S., Wooditch, A., and Gabbidon, S.L. 2014. Is criminology out-of-date? A research note on the use of common types of data. Journal of Criminal Justice Education, 25(1): 16 - 33.

Odgers, C.L., Caspi, A., Bates, C.J., Sampson, R.J., and Moffitt, T.E. 2013. "Systematic social observation of children's neighborhoods using Google Street View: A reliable and cost-effective method." Journal of Child Psychology and Psychiatry, 53(10): 10091017.

Osgood, D. Wayne. 2000. "Poisson-Based Regression Analysis of Aggregate Crime Rates." Journal of Quantitative Criminology 16(1): 21-43.

Park, R.E., and Burgess, E.W. 1924. Introduction to the Science of Sociology. 2d ed. Chicago: Univ. of Chicago Press.

Pearson-Merkowitz, Shanna. 2012. "The Limits of the Homogeneity Model: Segregation and Civic Engagement in Latino Communities." American Politics Research 40(4): 701-36.

Peterson, Ruth D., and Lauren J. Krivo. 1999. "Racial Segregation, the Concentration of Disadvantage, and Black and White Homicide Victimization." Sociological Forum 14(3): 465-493.

Putnam, Robert D. 2001. Bowling Alone: The Collapse and Revival of American Community. New York, NY: Simon \& Schuster.

Quillian, Lincoln. 2014. "Does Segregation Create Winners and Losers? Residential Segregation and Inequality in Educational Attainment." Social Problems 61: 402-426.

Raudenbush, Stephen W., and Robert J. Sampson. 1999. “Ecometrics: Toward a Science of Assessing Ecological Settings, with Application to the Systematic Social Observation of Neighborhoods." Sociological Methodology 29: 1-41. 
Reardon, Sean F., and Glenn Firebaugh. 2002. "Measures of multigroup segregation.' Sociological methodology32: 33-67.

Redden, Joanna. 2017. "Six Ways (and Counting) That Big Data Systems are Harming Society." The Conversation, December 7, 2017. Retrieved from:

https://orca.cardiff.ac.uk/107923/1/107923 Redden.pdf

Sampson, Robert J., Jeffrey D. Morenoff, and Felton Earls. 1999. "Beyond Social Capital: Spatial Dynamics of Collective Efficacy for Children." American Sociological Review 64(5): 633.

Sampson, Robert J., and Stephen W. Raudenbush. 1999. "Systematic Social Observation of Public Spaces: A New Look at Disorder in Urban Neighborhoods." The American Journal of Sociology 105(3): 603-651.

Sampson, Robert J., and Stephen W. Raudenbush. 2004. "Seeing Disorder: Neighborhood Stigma and the Social Construction of 'Broken Windows.'” Social Psychology Quarterly 67(4): 319-342.

Sampson, Robert J., and William J. Wilson. 1995. “Toward a Theory of Race, Crime, and Urban Inequality." Pp. 37-56 in Crime and Inequality, edited by J. Hagan and R. D. Peterson. Stanford, CA: Stanford University Press.

Semuels, Alana. 2016. "How Segregation Has Persisted in Little Rock." The Atlantic, April 27.

Shaw, C.R., and McKay, H.D. 1942. Juvenile Delinquency and Urban Areas. Chicago: University of Chicago Press.

Shihadeh, Edward S., 2009. "Race, Class and Crime: Reconsidering the Effects of Social Isolation and Crime. Deviant Behavior 30: 349-378.

Shihadeh, Edward S., and Nicole Flynn. 1996. "Segregation and Crime: The Effect of Black Social Isolation on the Rates of Black Urban Violence." Social Forces 74(4): 1325.

Sohn, Dong-Wook. 2016. "Residential Crimes and Neighbourhood Built Environment: Assessing the Effectiveness of Crime Prevention Through Environmental Design (CPTED)." Cities 52:86-93. 
Sorg, Evan T., and Ralph B. Taylor. 2011. "Community-level impacts of temperature on urban street robbery." Journal of Criminal Justice 39: 463-470.

Stolzenberg, Lisa, Stewart J. D’Alessio, and David Eitle. 2004. "A Multilevel Test of Racial Threat Theory." Criminology 42(3): 673-98.

Stucky, Thomas D. and John R. Ottensmann. 2009. “Land Use and Violent Crime.” Criminology, 47(4): 1223-1264.

Sytsma, V.A., Connealy, N., and Piza, E.L. 2021. “Environmental predictors of a drug offender crime script: A systematic social observation of Google Street View Images and CCTV Footage." Crime \& Delinquency, 67(1): 27-57.

Thomas, Shaun A., and Grant Drawve. 2018. "Examining Interactive Effects of Characteristics of the Social and Physical Environment on Aggravated Assault." Journal of Criminal Justice 57:89-98.

Thomas, William Isaac, and Florian Zaniecki. 1919. The Polish peasant in Europe and America: Monograph of an immigrant group (Vol. 3). Chicago: University of Chicago Press.

Tolbert, Charles M., Thomas A. Lyson, and Michael D. Irwin. 1998. "Local Capitalism, Civic Engagement, and Socioeconomic Well-Being." Social Forces 77: 401-29.

Vandeviver, C. 2014. "Applying Google Maps and Google Street View in environmental criminological research." Crime Science 3(1): 1-16.

Velez, M. B. 2006. "Toward an Understanding of the Lower Rates of Homicide in Latino versus Black Neighborhoods: A Look at Chicago.” Pp. 91-107 in The Many Colors of Crime: Inequalities of Race, Ethnicity, and Crime in America, edited by R. D. Peterson, L. J. Krivo, and J. Hagan. New York: New York University Press.

Vercruyssen, Anina, and Geert Loosveldt. 2017. “Using Google Maps and Google Street View to Validate Interviewer Observations and Predict Non-response: A Test Case." In Survey Research Methods, vol. 11, no. 3, pp. 345-360.

Weisburd, David. 2015. "The 2014 Sutherland Address: The Law of Crime Concentration and the Criminology of Place." Criminology, 53(2): 133-157.

Wilkes, Rima, and John Iceland. 2004. "Hypersegregation in the Twenty-First Century." Demography 41(1): 23-36. 
Williams, David R., and Chiquita Collins. 2001. "Racial Residential Segregation: A Fundamental Cause of Racial Disparities in Health." Public Health Reports 116(5): 404416.

Wilson, William Julius. 1987. The Truly Disadvantaged. University of Chicago Press.

Woodward, V.H., Webb, M.E., Griffen, H., and Copes, H. 2016. "The current state of criminological research in the United States: An examination of research methodologies in criminology and criminal justice journals." Journal of Criminal Justice Education, 27(3): 340-361.

Xie, Min. 2010. "The Effects of Multiple Dimensions of Residential Segregation on Black and Hispanic Homicide Victimization." Journal of Quantitative Criminology 26(2): 237-268.

\section{Tables}

Table 1: Means and Standard Deviations (in parentheses) for Crime Rates, Permeability Variables, and Key Controls for All Block Groups and by High/Low Black Isolation Block Groups in Little Rock, AR in 2014-2016

\begin{tabular}{|c|c|c|c|c|c|c|c|}
\hline & \multicolumn{2}{|c|}{$\begin{array}{l}\text { All Block } \\
\text { Groups }\end{array}$} & \multicolumn{2}{|c|}{$\begin{array}{l}\text { Low Black } \\
\text { Isolation }{ }^{a}\end{array}$} & \multicolumn{2}{|c|}{$\begin{array}{l}\text { High Black } \\
\text { Isolation }^{\mathrm{a}}\end{array}$} & $\begin{array}{l}\text { High } \\
\text { vs. } \\
\text { Low }\end{array}$ \\
\hline & \multicolumn{2}{|c|}{$(\mathrm{N}=124)$} & \multicolumn{2}{|c|}{$(\mathrm{N}=31)$} & \multicolumn{2}{|c|}{$(\mathrm{N}=31)$} & $\begin{array}{l}\% \\
\text { Diff. }\end{array}$ \\
\hline & (1) & (2) & (3) & (4) & (5) & (6) & (7) \\
\hline \multicolumn{8}{|l|}{$\begin{array}{l}\text { Depe } \\
\text { ndent } \\
\text { Varia } \\
\text { bles: }\end{array}$} \\
\hline $\begin{array}{l}\text { Homi } \\
\text { cide } \\
\text { Rate }\end{array}$ & .30 & $(.48)$ & .04 & (.13) & .64 & (.68) & $\begin{array}{l}1500 . \\
00 \%\end{array}$ \\
\hline
\end{tabular}




\begin{tabular}{|c|c|c|c|c|c|c|c|}
\hline $\begin{array}{l}\text { Agg. } \\
\text { Assau } \\
\text { lt } \\
\text { Rate }\end{array}$ & 7.70 & $(7.10)$ & 2.37 & (3.91) & 13.21 & (8.32) & $\begin{array}{l}457.3 \\
8 \%\end{array}$ \\
\hline $\begin{array}{l}\text { Burgl } \\
\text { ary } \\
\text { Rate }\end{array}$ & 10.94 & 6.83 & 6.13 & $(5.55)$ & 13.89 & (7.85 & $\begin{array}{l}126.5 \\
9 \%\end{array}$ \\
\hline $\begin{array}{l}\text { Larce } \\
\text { ny } \\
\text { Rate }\end{array}$ & 50.62 & 51.69 & 44.72 & $\begin{array}{l}(65.4 \\
5)\end{array}$ & 51.23 & 51.53 & $\begin{array}{l}14.56 \\
\%\end{array}$ \\
\hline $\begin{array}{l}\text { Perm } \\
\text { eabili } \\
\text { ty } \\
\text { Varia } \\
\text { bles: }\end{array}$ & & & & & & & \\
\hline $\begin{array}{l}\text { Avg. } \\
\text { Thru- } \\
\text { Stree } \\
\text { ts }\end{array}$ & 1.71 & (1.33) & 1.05 & (.65) & 2.63 & (1.66) & $\begin{array}{l}150.4 \\
8 \%\end{array}$ \\
\hline $\begin{array}{l}\text { Avg. } \\
\text { Walk } \\
\text { Time }\end{array}$ & 34.88 & $\begin{array}{l}(19.8 \\
9)\end{array}$ & 45.43 & $\begin{array}{l}(25.3 \\
5)\end{array}$ & 26.92 & $\begin{array}{l}(15.3 \\
4)\end{array}$ & $\begin{array}{l}-40.7 \\
4 \%\end{array}$ \\
\hline $\begin{array}{l}\text { Segre } \\
\text { gatio } \\
n:\end{array}$ & & & & & & & \\
\hline $\begin{array}{l}\text { Black } \\
\text { Isolat } \\
\text { ion }\end{array}$ & .67 & (.27) & .27 & (.13) & .95 & $(.03)$ & $\begin{array}{l}251.8 \\
5 \%\end{array}$ \\
\hline $\begin{array}{l}\text { Contr } \\
\text { ol } \\
\text { Varia } \\
\text { bles: }\end{array}$ & & & & & & & \\
\hline
\end{tabular}




\begin{tabular}{|c|c|c|c|c|c|c|c|}
\hline $\begin{array}{l}\% \\
\text { Pover } \\
\text { ty }\end{array}$ & 21.75 & $\begin{array}{l}(14.8 \\
9)\end{array}$ & 11.48 & $\begin{array}{l}(18.1 \\
0)\end{array}$ & 29.15 & $\begin{array}{l}(13.7 \\
2)\end{array}$ & $\begin{array}{l}153.9 \\
2 \%\end{array}$ \\
\hline $\begin{array}{l}\% \\
\text { w/o } \\
\text { High } \\
\text { Scho } \\
\text { ol } \\
\text { Degr } \\
\text { ee }\end{array}$ & 13.96 & $\begin{array}{l}(10.7 \\
8)\end{array}$ & 4.84 & $(7.03)$ & 22.09 & $\begin{array}{l}(10.4 \\
2)\end{array}$ & $\begin{array}{l}356.4 \\
0 \%\end{array}$ \\
\hline $\begin{array}{l}\% \\
\text { Fema } \\
\text { le } \\
\text { Head } \\
\text { ship }\end{array}$ & 13.33 & $(9.62)$ & 7.81 & $(6.22)$ & 17.49 & $(9.36)$ & $\begin{array}{l}123.9 \\
4 \%\end{array}$ \\
\hline $\begin{array}{l}\% \\
\text { SNAP } \\
\text { Benef } \\
\text { its }\end{array}$ & 17.65 & $\begin{array}{l}(12.7 \\
5)\end{array}$ & 5.71 & 5.88) & 25.03 & $\begin{array}{l}(12.6 \\
5)\end{array}$ & $\begin{array}{l}338.3 \\
5 \%\end{array}$ \\
\hline $\begin{array}{l}\% \\
\text { White }\end{array}$ & 35.50 & $\begin{array}{l}(25.2 \\
6)\end{array}$ & 65.04 & $\begin{array}{l}(13.9 \\
6)\end{array}$ & 9.08 & (6.87) & $\begin{array}{l}-86.0 \\
4 \%\end{array}$ \\
\hline $\begin{array}{l}\% \\
\text { Black }\end{array}$ & 54.45 & $\begin{array}{l}(26.7 \\
3)\end{array}$ & 23.81 & $\begin{array}{l}(12.4 \\
3)\end{array}$ & 83.76 & $\begin{array}{l}(12.7 \\
3)\end{array}$ & $\begin{array}{l}251.7 \\
8 \%\end{array}$ \\
\hline $\begin{array}{l}\% \\
\text { Hispa } \\
\text { nic }\end{array}$ & 6.32 & $(9.86)$ & 4.63 & $(7.10)$ & 5.13 & $\begin{array}{l}(11.1 \\
0)\end{array}$ & $\begin{array}{l}10.80 \\
\%\end{array}$ \\
\hline $\begin{array}{l}\text { Pop. } \\
\text { Densi } \\
\text { ty } \\
\text { (logg } \\
\text { ed) }\end{array}$ & 7.71 & $(.85)$ & 7.71 & $(.75)$ & 7.74 & (.79) & $\begin{array}{l}0.39 \\
\%\end{array}$ \\
\hline \multicolumn{8}{|c|}{$\begin{array}{l}\text { Note: Crime rates are displayed as rates per 1,000 for ease of interpretation, but all models } \\
\text { use crime counts with exposure terms for total population. Control variables for poverty, } \\
\text { education, female headship, and SNAP benefits are combined together using PCA for all }\end{array}$} \\
\hline
\end{tabular}


a Low Black isolation reflects the lowest quartile of block groups (least Black isolation), whereas high Black isolation represents the highest quartile (most Black isolation).

Table 2. Negative Binomial Models Regressing Crime Counts on Measures of Permeability and Key Controls Across Little Rock Block Groups (N=124), 2015

\begin{tabular}{|c|c|c|c|c|c|c|c|c|c|c|c|c|c|c|c|c|}
\hline & \multicolumn{4}{|c|}{ Homicide } & \multicolumn{4}{|c|}{ Agg Assault } & \multicolumn{4}{|c|}{ Burglary } & \multicolumn{4}{|c|}{ Larceny } \\
\hline & $\mathrm{b}$ & IRR & $\mathrm{b}$ & IRR & $\mathrm{b}$ & IRR & $\mathrm{b}$ & IRR & $\mathrm{b}$ & IRR & $\mathrm{b}$ & IRR & $\mathrm{b}$ & IRR & $\mathrm{b}$ & IRR \\
\hline $\begin{array}{l}\text { Per } \\
\text { me } \\
\text { abil } \\
\text { ity: }\end{array}$ & & & & & & & & & & & & & & & & \\
\hline $\begin{array}{l}\text { Avg } \\
\text { Thr } \\
\text { u- } \\
\text { Str } \\
\text { eet } \\
\text { s }\end{array}$ & .10 & $\begin{array}{l}1.1 \\
0\end{array}$ & - & - & $\begin{array}{l}.23 \\
* * *\end{array}$ & $\begin{array}{l}1.2 \\
6\end{array}$ & - & - & $\begin{array}{l}.10 \\
*\end{array}$ & $\begin{array}{l}1.0 \\
9\end{array}$ & - & - & $\begin{array}{l}.26 \\
* * *\end{array}$ & $\begin{array}{l}1.3 \\
0\end{array}$ & - & - \\
\hline & $\begin{array}{l}(.0 \\
9)\end{array}$ & & - & & $\begin{array}{l}(.0 \\
5)\end{array}$ & & - & & $\begin{array}{l}(.04 \\
)\end{array}$ & & - & & $\begin{array}{l}(.06 \\
)\end{array}$ & & - & \\
\hline $\begin{array}{l}\text { Avg } \\
\cdot \\
\text { Wal } \\
\mathrm{k} \\
\mathrm{Ti} \\
\mathrm{me} \\
\mathrm{a}\end{array}$ & - & - & $\begin{array}{l}-.03 \\
* *\end{array}$ & $\begin{array}{l}0.9 \\
7\end{array}$ & - & - & $\begin{array}{l}-.03 \\
* *\end{array}$ & $\begin{array}{l}0.9 \\
7\end{array}$ & - & - & $\begin{array}{l}-.02 \\
* *\end{array}$ & $\begin{array}{l}0.9 \\
8\end{array}$ & - & - & $\begin{array}{l}-.02 \\
* *\end{array}$ & $\begin{array}{l}0.9 \\
8\end{array}$ \\
\hline
\end{tabular}




\begin{tabular}{|c|c|c|c|c|c|c|c|c|c|c|c|c|c|c|c|c|}
\hline & - & & $\begin{array}{l}(.0 \\
1)\end{array}$ & & - & & $\begin{array}{l}(.01 \\
)\end{array}$ & & - & & $\begin{array}{l}(.01 \\
)\end{array}$ & & - & & $\begin{array}{l}(.01 \\
)\end{array}$ & \\
\hline $\begin{array}{l}\text { Seg } \\
\text { reg } \\
\text { atio } \\
\text { n: }\end{array}$ & & & & & & & & & & & & & & & & \\
\hline $\begin{array}{l}\text { Bla } \\
\text { ck } \\
\text { Iso. } \\
\text { (P* } \\
\text { ) }\end{array}$ & $\begin{array}{l}2.7 \\
0 * *\end{array}$ & $\begin{array}{l}14 . \\
88\end{array}$ & $\begin{array}{l}2.5 \\
5^{* *}\end{array}$ & $\begin{array}{l}12 . \\
78\end{array}$ & $\begin{array}{l}1.1 \\
3^{* *}\end{array}$ & $\begin{array}{l}1.1 \\
7\end{array}$ & $\begin{array}{l}1.4 \\
2^{* *}\end{array}$ & $\begin{array}{l}4.1 \\
3\end{array}$ & $\begin{array}{l}1.0 \\
4^{* *}\end{array}$ & $\begin{array}{l}2.8 \\
2\end{array}$ & $\begin{array}{l}1.0 \\
4^{* *}\end{array}$ & $\begin{array}{l}2.8 \\
3\end{array}$ & .04 & $\begin{array}{l}1.0 \\
4\end{array}$ & .18 & $\begin{array}{l}1.2 \\
0\end{array}$ \\
\hline & $\begin{array}{l}(.9 \\
1)\end{array}$ & & $\begin{array}{l}(.8 \\
5)\end{array}$ & & $\begin{array}{l}(.3 \\
8)\end{array}$ & & $\begin{array}{l}(.35 \\
)\end{array}$ & & $\begin{array}{l}(.32 \\
)\end{array}$ & & $\begin{array}{l}(.29 \\
)\end{array}$ & & $\begin{array}{l}(.37 \\
)\end{array}$ & & $\begin{array}{l}(.36 \\
)\end{array}$ & \\
\hline $\begin{array}{l}\text { Con } \\
\text { Vari } \\
:\end{array}$ & $\begin{array}{l}\text { rol } \\
\text { ables }\end{array}$ & & & & & & & & & & & & & & & \\
\hline $\begin{array}{l}\text { Dis } \\
\text { adv }\end{array}$ & $\begin{array}{l}.19 \\
*\end{array}$ & $\begin{array}{l}1.2 \\
1\end{array}$ & .10 & $\begin{array}{l}1.1 \\
1\end{array}$ & $\begin{array}{l}.22 \\
* * *\end{array}$ & $\begin{array}{l}1.2 \\
5\end{array}$ & $\begin{array}{l}.13 \\
* *\end{array}$ & $\begin{array}{l}1.1 \\
4\end{array}$ & .04 & $\begin{array}{l}1.0 \\
4\end{array}$ & -.01 & $\begin{array}{l}0.9 \\
9\end{array}$ & $\begin{array}{l}.11 \\
*\end{array}$ & $\begin{array}{l}1.1 \\
2\end{array}$ & .04 & $\begin{array}{l}1.0 \\
4\end{array}$ \\
\hline & $\begin{array}{l}(.1 \\
0)\end{array}$ & & $\begin{array}{l}(.1 \\
0)\end{array}$ & & $\begin{array}{l}(.0 \\
5)\end{array}$ & & $\begin{array}{l}(.01 \\
)\end{array}$ & & $\begin{array}{l}(.05 \\
2)\end{array}$ & & $\begin{array}{l}(.05 \\
)\end{array}$ & & $\begin{array}{l}(.05 \\
)\end{array}$ & & $\begin{array}{l}(.06 \\
)\end{array}$ & \\
\hline $\begin{array}{l}\text { Spa } \\
\text { tial } \\
\text { Lag } \\
\text { b }\end{array}$ & -.07 & $\begin{array}{l}0.9 \\
4\end{array}$ & -.01 & $\begin{array}{l}0.9 \\
9\end{array}$ & $\begin{array}{l}.02 \\
* *\end{array}$ & $\begin{array}{l}1.0 \\
2\end{array}$ & $\begin{array}{l}.02 \\
* *\end{array}$ & $\begin{array}{l}1.0 \\
2\end{array}$ & .01 & $\begin{array}{l}1.0 \\
0\end{array}$ & .01 & $\begin{array}{l}1.0 \\
0\end{array}$ & .01 & $\begin{array}{l}1.0 \\
0\end{array}$ & .01 & $\begin{array}{l}1.0 \\
0\end{array}$ \\
\hline & $\begin{array}{l}(.2 \\
4)\end{array}$ & & $\begin{array}{l}(.2 \\
2)\end{array}$ & & $\begin{array}{l}(.0 \\
1)\end{array}$ & & $\begin{array}{l}(.01 \\
)\end{array}$ & & $\begin{array}{l}(.01 \\
)\end{array}$ & & $\begin{array}{l}(.01 \\
)\end{array}$ & & $\begin{array}{l}(.01 \\
)\end{array}$ & & $\begin{array}{l}(.01 \\
)\end{array}$ & \\
\hline \multicolumn{17}{|c|}{$\begin{array}{l}\text { Note: Incident rate ratios provided for ease of interpreting magnitude. All models include a } \\
\text { multi-group entropy score for diversity, logged population density, an exposure term for the } \\
\text { total population, and employ tract-clustered standard errors (in parentheses). }\end{array}$} \\
\hline
\end{tabular}




\begin{tabular}{l}
$\begin{array}{l}\text { a Averaged for all neighbors and } \\
\text { adjusted for Euclidean distance. }\end{array}$ \\
$\begin{array}{l}\text { b Calculated for each offense separately } \\
\text { using row-standardized Queen's 1st order. }\end{array}$ \\
$\begin{array}{l}* \mathrm{p} \\
\mathrm{p}<.05, * * \\
\mathrm{p}<.01, * * *\end{array}$ \\
\hline
\end{tabular}

Table 3. Negative Binomial Models Regressing Crime Counts on (A) Average Thru-Streets, (B) Average Walk Times, Spatial Lags of Crime, and Key Controls for High $(\mathrm{N}=31)$ and Low $(\mathrm{N}=31)$ Black Isolation Block Groups in Little Rock, 2014-2016

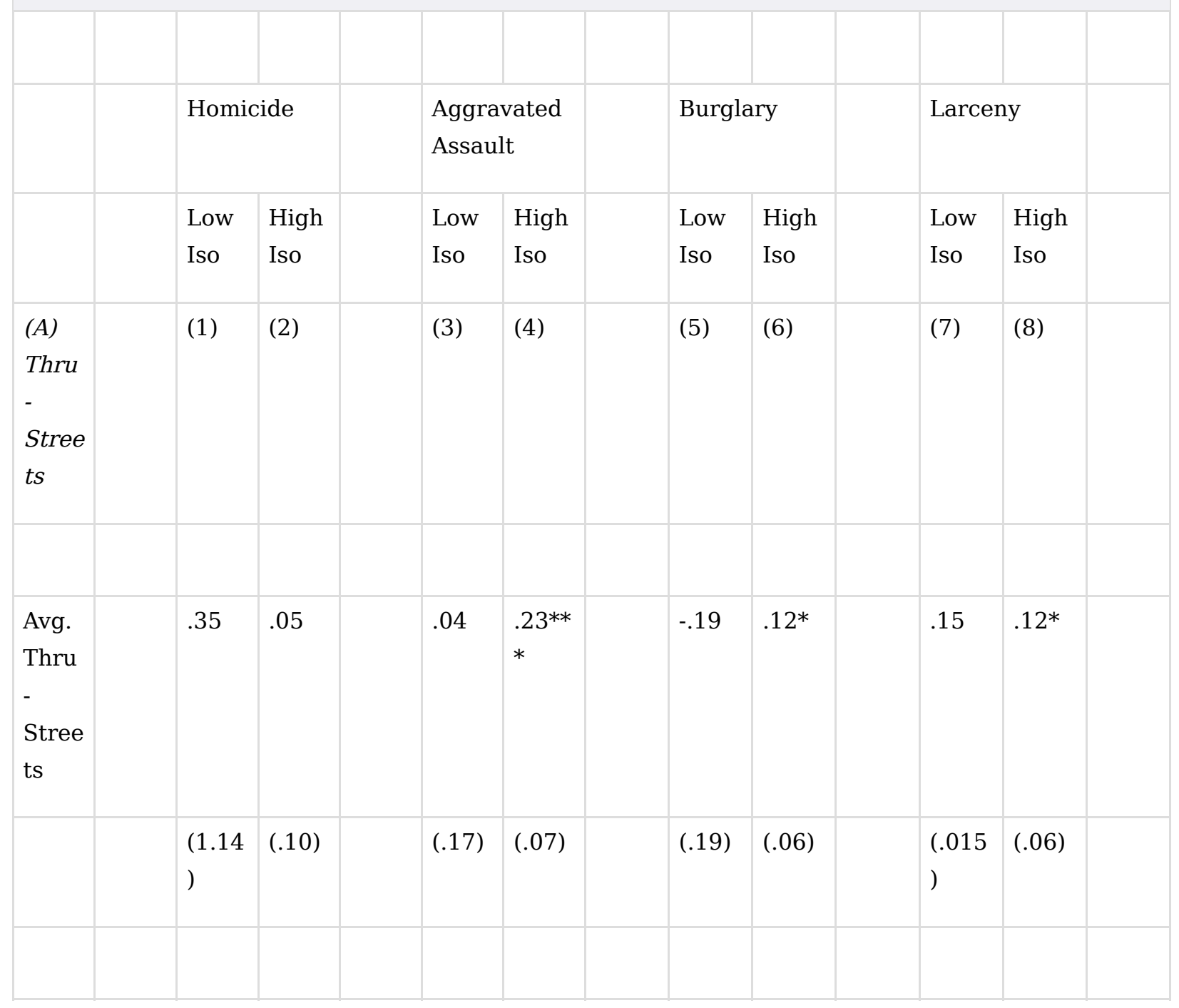




\begin{tabular}{|c|c|c|c|c|c|c|c|c|}
\hline \multirow{2}{*}{$\begin{array}{l}\text { Disa } \\
\text { dvan } \\
\text { tage }\end{array}$} & .59 & .01 & $.45^{* *}$ & .10 & -.24 & -.01 & .23 & .08 \\
\hline & (.67) & $(.17)$ & $(.15)$ & $(.08)$ & $(.24)$ & $(.08)$ & $(.16)$ & (.09) \\
\hline \multirow{4}{*}{$\begin{array}{l}\text { Spati } \\
\text { al } \\
\text { Lag }{ }^{b}\end{array}$} & 1.85 & .48 & $.05 *$ & $.03 *$ & .01 & .01 & .01 & .01 \\
\hline & (2.61 & $(.43)$ & $(.02)$ & $(.01)$ & $(.01)$ & -0.01 & $(.01)$ & $(.01)$ \\
\hline & \multicolumn{2}{|c|}{ Homicide } & \multicolumn{2}{|c|}{ Agg. Assault } & \multicolumn{2}{|c|}{ Burglary } & \multicolumn{2}{|c|}{ Larceny } \\
\hline & $\begin{array}{l}\text { Low } \\
\text { Iso }\end{array}$ & $\begin{array}{l}\text { High } \\
\text { Iso }\end{array}$ & $\begin{array}{l}\text { Low } \\
\text { Iso }\end{array}$ & $\begin{array}{l}\text { High } \\
\text { Iso }\end{array}$ & $\begin{array}{l}\text { Low } \\
\text { Iso }\end{array}$ & $\begin{array}{l}\text { High } \\
\text { Iso }\end{array}$ & $\begin{array}{l}\text { Low } \\
\text { Iso }\end{array}$ & $\begin{array}{l}\text { High } \\
\text { Iso }\end{array}$ \\
\hline $\begin{array}{l}(B) \\
\text { Walk } \\
\text { Time }\end{array}$ & (1) & (2) & (3) & $(4)$ & (5) & (6) & (7) & (8) \\
\hline \multirow{2}{*}{$\begin{array}{l}\text { Avg. } \\
\text { Walk } \\
\text { Time } \\
\text { a }\end{array}$} & -.01 & $-.03 *$ & -.01 & $\begin{array}{l}-.04 * \\
* *\end{array}$ & -.01 & $\begin{array}{l}-.02 * \\
*\end{array}$ & $\begin{array}{l}-.01 * \\
*\end{array}$ & $\begin{array}{l}-.03 * \\
*\end{array}$ \\
\hline & $(.02)$ & $(.01)$ & $(.01)$ & $(.01)$ & $(.01)$ & $(.01)$ & $(.01)$ & $(.01)$ \\
\hline \multirow{2}{*}{$\begin{array}{l}\text { Disa } \\
\text { dvan } \\
\text { tage }\end{array}$} & .53 & -0.03 & $.42^{* *}$ & .03 & -.24 & -.06 & .16 & .01 \\
\hline & (.63) & $(.16)$ & $(.15)$ & $(.07)$ & $(.24)$ & $(.07)$ & (.15) & (.09) \\
\hline $\begin{array}{l}\text { Spati } \\
\text { al } \\
\text { Lag }^{b}\end{array}$ & 1.42 & .39 & $.04 *$ & $.02 *$ & -.01 & .01 & .01 & .01 \\
\hline
\end{tabular}




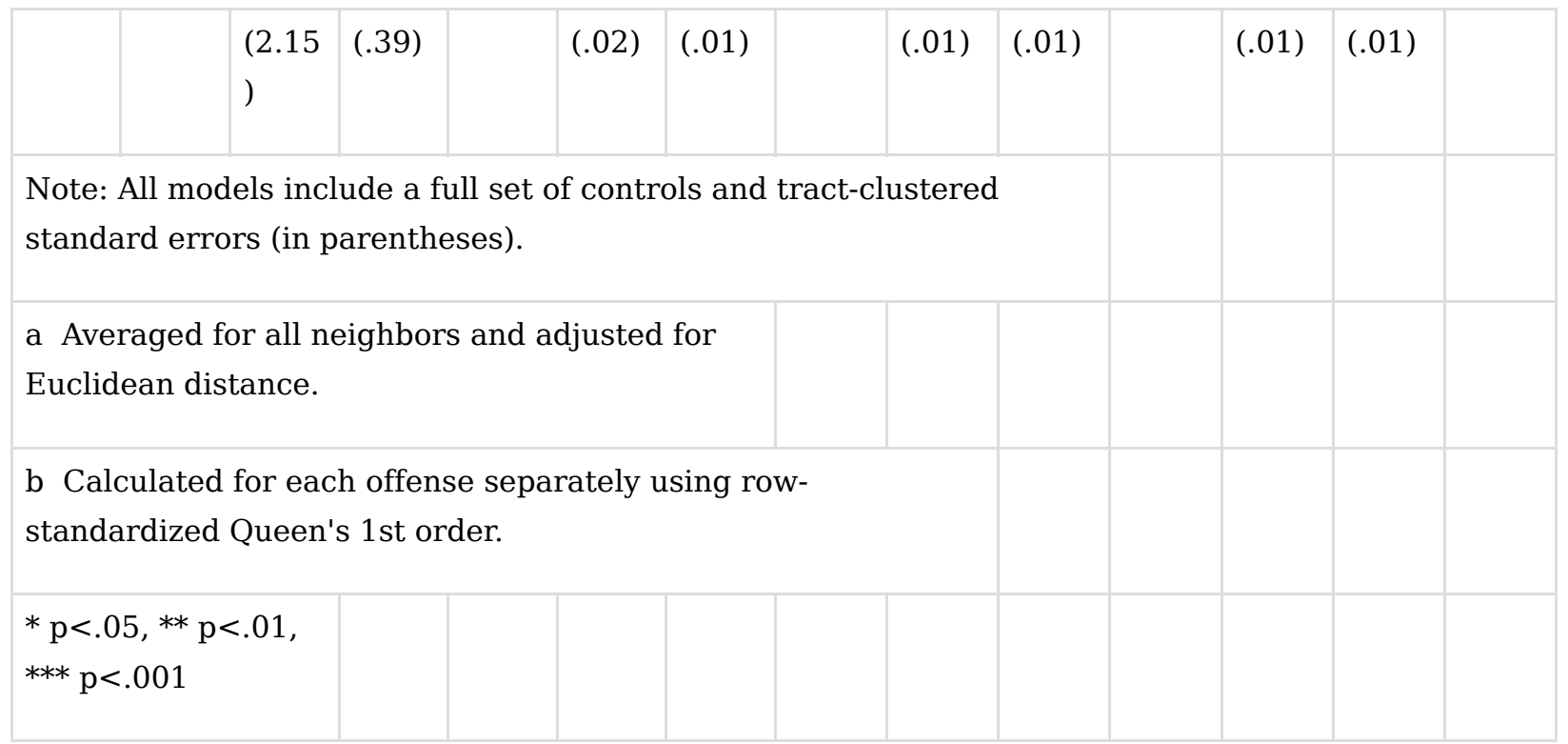

